\title{
Interplanting Soybean with Three Species of Orchard Trees Under Two Soybean Plant Distributions in Sandy Soils
}

\author{
Mohamed AF Selim ${ }^{1 *}$, Yaser AA Hefny ${ }^{2}$ and Mostafa AM Ebrahim ${ }^{3}$ \\ ${ }^{1}$ Citrus Research Department, Horticulture Research Institute, Agricultural \\ Research Center, Egypt \\ ${ }^{2}$ Crop Intensification Research Department, Field Crops Research Institute, \\ Agricultural Research Center, Egypt \\ ${ }^{3}$ Food Legumes Research Department, Field Crops Research Institute, Agricultural \\ Research Center, Egypt \\ *Corresponding Author: Mohamed AF Selim, Citrus Research Department, \\ Horticulture Research Institute, Agricultural Research Center, Egypt.
}

DOI: $10.31080 /$ ASAG.2020.04.0875

\begin{abstract}
A two-year study was carried out at El-Kassaseen Agricultural Research Station, Agricultural Research Center (ARC), Ismailia government, Egypt, during 2018 and 2019 summer seasons to evaluate the optimum interplanting system of soybean with orange, mandarin and mango for achieving high productivity of crops, land usage, and profitability under sandy soil conditions. Ten treatments were the combinations of three orchards trees (mango, orange and mandarin) and two soybean plant distributions with the same plant density (one row/ridge and two rows/ridge) in a strip plot design with three replications were taken. The rhizosphere of mandarin trees had higher soil $\mathrm{CO}_{2}$ and organic carbon (OC), meanwhile the reverse was true for mango trees under interplanting conditions. Wide soybean plant distribution increased fruit yield per ha by 10.23 and $10.06 \%$ for orange trees and by 7.49 and $6.29 \%$ for mandarin trees in the first and second seasons, respectively than the narrow one as a result of increased soil $\mathrm{CO}_{2}$ and $\mathrm{OC}$, meanwhile, all the studied traits of mango trees were not affected. On the other hand, interplanting soybean with mandarin trees recorded higher light intensity at the middle of soybean plant, the number of branches and pods per plant, as well as seed yields per plant and per ha than the other interplanting systems soybean + orange and soybean + mango in both seasons. Also, wide soybean plant distribution gave higher all the studied soybean traits (except plant height) than the narrow one in both seasons. Moreover, soybean of wide plant distribution in soybean + mandarin system gave higher all the studied soybean traits (except plant height) compared with the other treatments in both seasons. Land equivalent ratio (LER) and land equivalent coefficient (LEC) values for intercrops were much greater than 1.00 and 0.25 , respectively, indicating the advantage of the interplanting system than solid culture of the studied orchards. Growing four ridges of soybean variety Giza 22 (one row per ridge at distance $25 \mathrm{~cm}$ between hills) between mango trees cultivar Naomy is more profitable for Egyptian farmers followed by growing four ridges of the same soybean variety (two soybean rows per ridge at distance $50 \mathrm{~cm}$ between hills) with mandarin trees (Fremont cultivar).
\end{abstract}

Keywords: Interplanting; Orchard Species; Soybean Plant Distribution; Soil $\mathrm{CO}_{2}$; Soil OC; Competitive Relationships; Economic Return

\section{Introduction}

Fruits are essential for the proper maintenance of human health [1]. Citrus fruits are recognized as an important component of the human diet, providing a variety of constituents important to human nutrition, including vitamin C (ascorbic acid), folic acid, potassium, flavonoids, coumarins, pectin and dietary fibers [2].
There are major species such as sweet orange (Citrus sinensis (L.) Osbeck), mandarin (Citrus reticulata Blanco), grapefruits (Citrus paradisi), lime (Citrus aurantifolia) and sour orange (Citrus aurantium L.) are grown in Egypt [3]. World citrus production is dominated by Mediterranean region contributing 20\%, respectively [4]. Citrus trees occupy a significant economic importance among fruit crops in Egypt. Egypt represents about $15 \%$ of the total citrus 
production in the Mediterranean Basin [5] and is considered the ninth largest citrus producer in the world [6] with a global market share of $3.1 \%$ of the world citrus production [7]. It is known that mandarin occupies the second planted citrus species after orange [8]. Accordingly, Egypt is one of the world's leading orange producers and exporters rank as the sixth orange producer in the world after Brazil, China, USA, EU, and Mexico where oranges represent around 30 percent of the total Egyptian fruit production and 65 percent of citrus production [9]. Therefore, Egyptian growers are encouraged to cultivate citrus varieties, especially oranges instead of other crops, since 2006 (around 50\% increases) due to the extension in the newly reclaimed desert areas [10].

On the other hand, the fruit mango (Mangifera indica L.) is eaten fresh and in several other by-products, including juices, nectars, purees [11]. It is one of the popular and economically important tropical fruit throughout the world and it belongs to the family Anacardiaceae, originated in South Asia or Malayan archipelago [12]. The normal yield of mango ranged from 5.6 to $18.7 \mathrm{t} / \mathrm{ha}$ and the most producing centers are in Sharkia, Ismailia, Giza, Fayoum, Qena and Beheira Governorates [13]. Central and South America, Australia, Southeast Asia, Hawaii, Egypt and South Africa are outside the traditional geographical regions for mango production and are increasing the mango cultivations especially for export markets [14]. It is known that mango is ranked as the second most cultivated tropical fruit, and the sixth major fruit crop worldwide [15].

Many investigations enumerated the decline of citrus trees to the unfavorable surface and subsurface soil conditions [16]. Due to weed competition, fruit trees mostly suffer from water stress and also have an impact on yield and quality of fruits [17]. Also, micronutrients deficiency became limiting factors for growth which leads to low yield and reduces fruit quality [18] where soils of orchards are sandy in nature with poor levels of phosphorus (P), potassium (K) and micronutrients [19]. It is known that soil $\mathrm{pH}$ is determined by the concentration of hydrogen ions $(\mathrm{H}+)$. It is a measure of the soil solution's (soil water together with its dissolved substances) acidity and alkalinity, on a scale from 0 to 14 [20]. So if the interspaces of orchards are utilized by growing legumes, that are compatible with the main crop, they not only improve the physical conditions of soils but also enhances the uptake of moisture and nutrients. Thus, a reduction of tillage intensity is normally needed to effectively reduce $\mathrm{CO}_{2}$ emissions, enhance soil C sequestration, and increase soil water availability [21]. Soil OC increases when sandy soils were fertilized, but sandy soils become more water repellent with an increase in soil OC and a decrease in $\mathrm{pH}$ [22]. Consequently, there is a need to use other sources of nutrients to maintain productivity and fertility of soil orchards at a required level. This can be achieved through the effective use of a suitable cropping system.
Soybean (Glycine max L.) is a major legume crop in tropical and sub-tropical areas all over the world. In Egypt, there is a decline in area under soybean in the Nile Valley and Delta, where it reached to about 13,440 thousand ha in 2018 [23]. It is not feasible to expand soybean area because of high competition from the other summer crops. However, it is feasible to increase the acreage of soybean in newly reclaimed lands through interplanting with orchards.

The use of intercropping culture could be playing an important role in maximizing land equivalent ratio under low conditions of sandy soil. Multiple cropping can be done in annual food crops, fodders, vegetables, fruit plants and perennial crops [24]. Lachungpa [25] revealed that interplanting some crops with mandarins provided farmers with increased food security and opportunities for cash flow. Thus, intercropping legumes in orchards is beneficial for the total production.

According to Agreda., et al. [26], mango yield was highest in combination with Phaseolus acutifolius and Cajanus cajan. Also, Mulinge., et al. [27] showed that cowpea (Vigna unguiculata) increased orange fruit brix by 4.6, 3.8 and 3.2\% for Vitengeni, Matuga and Ganda, respectively. Moreover, soybean [Glycine max (L.) Merr.] improved mandarin yield compared with sole mandarin by fixing $\mathrm{N}$ biologically in the soil [28]. However, Selim., et al. [28] showed that shading of mandarin trees had negative effects on light intensity at the middle of the plant and plant dry weight after 75 days from soybean sowing both seasons compared with soybean solid culture.

Row arrangement, in contrast to arrangement of component crops within rows, may influence the productivity of an intercropping system [29] where it is expected that soybean plant spacing will change spatial arrangement of interplanting soybean with orchards. Spatial arrangement has an important influence on the degree of competition between crops [30]. Meanwhile, there were non-significant differences between 60 and $80 \mathrm{~cm}$ ridge width for the studied soybean traits [31].

\section{Objective of the Study}

The objective of this investigation was to evaluate the optimum interplanting system of soybean with orange, mandarin and mango for achieving high productivity of crops, land usage, and profitability under sandy soil conditions.

\section{Materials and Methods}

A two-year study was carried out at El-Kassaseen Agricultural Research Station, A.R.C., Ismailia Governorate (Lat. 30 35' 30" N, Long. $32^{\circ} 14^{\prime}$ 50" E, $10 \mathrm{~m}$ a.s.l.), Egypt during 2018 and 2019 seasons to evaluate the optimum interplanting system of soybean with orange, mandarin and mango for achieving high productivity of 
crops, land usage, and profitability under sandy soil conditions. As a result of exist the alternate bearing in orchards trees, four years old orchards trees (on-year bearing) were growing in distance $3 \mathrm{x}$ $4 \mathrm{~m}$ apart (833 trees per ha) subjected to experiments in the first season, meanwhile other group of trees (in the same bearing status) were chosen in the second year.

\section{The treatments}

\section{Orchard tree species}

Orange trees ( 4 years old) solid condition, with distance of $3 \mathrm{x}$ $4 \mathrm{~m}$ apart (833 orange trees/ha). Plant densities of soybean crop was $50 \%$ from solid crop condition (161280 soybean plants/ha).

Mandarin trees (4 years old) solid condition, with distance of $3 \times 4 \mathrm{~m}$ apart (833 mandarin trees/ha). Plant densities of soybean crop was $50 \%$ from solid crop condition (161280 soybean plants/ ha).

Mango trees ( 4 years old) solid condition, with distance of $3 \times 4$ $\mathrm{m}$ apart (833 mango trees/ha). Plant densities of soybean crop was $50 \%$ from solid crop condition (161280 soybean plants/ha).

\section{Soybean plant distributions}

Narrow plant distribution

Growing two soybean plants per hill, $25 \mathrm{~cm}$ apart, at one row of four ridges, $50 \mathrm{~cm}$ width. The border ridges of soybean distanced at $0.75 \mathrm{~m}$ from mandarin trees.

\section{Wide plant distribution}

Growing two soybean plants per hill, $50 \mathrm{~cm}$ apart, at both rows of four ridges, $50 \mathrm{~cm}$ width. The border ridges of soybean distanced at $0.75 \mathrm{~m}$ from mandarin trees.

Solid soybean was conducted by planting two soybean plants per hill, $25 \mathrm{~cm}$ apart, at both sides of eight ridges, $50 \mathrm{~cm}$ width (322560 soybean plants/ha). This system was used to estimate completive relationships.

The four years old mango, orange and mandarin trees cultivars were Naomy, Baladi and Fremont, respectively. Meanwhile, soybean variety was Giza 22 in this study. A strip plot design with three replications was used. Orchard tree species were randomly assigned to the vertical strips and soybean plant distributions were allocated in the horizontal strips. Each strip plot was $48 \mathrm{~m}^{2}(8 \mathrm{~m}$ in length and $6 \mathrm{~m}$ in width). Soybean plants were sown on June $2^{\text {nd }}$ and $5^{\text {th }}$ at 2018 and 2019 summer seasons, respectively. Mechanical and chemical analyses of the soil $(0-60 \mathrm{~cm})$ were done by Water, Soil and Environment Research Institute, ARC (Table 1). Mechanical and chemical properties of the soil were determined using the methods described by Chapman and Pratt [32].

\begin{tabular}{|l|c|c|}
\hline \multirow{2}{*}{\multicolumn{1}{c|}{$\begin{array}{c}\text { Depth of soil } \\
\text { (0 - 60 cm) }\end{array}$}} & $\begin{array}{c}\text { Growing season } \\
\text { (2018) }\end{array}$ & $\begin{array}{c}\text { Second season } \\
\text { (2019) }\end{array}$ \\
\cline { 2 - 3 } Mechanical analysis & & \\
\hline Clay (\%) & 11.87 & 11.72 \\
\hline Silt (\%) & 2.15 & 2.06 \\
\hline Sand (\%) & 85.98 & 86.22 \\
\hline Texture & Sandy & Sandy \\
\hline Chemical analysis & & \\
\hline pH & 8.15 & 8.10 \\
\hline E.C. (mmohs/cm) & 0.21 & 0.22 \\
\hline N (kg/ha) & 10.60 & 10.30 \\
\hline P (kg/ha) & 17.60 & 18.40 \\
\hline K (kg/ha) & 76.00 & 68.00 \\
\hline
\end{tabular}

Table 1: Mechanical and chemical properties of soil $(0-60 \mathrm{~cm})$ at experimental site before soybean planting.

Drip irrigation system was used in all tested treatments by separated nets for each crop owing to control the amounts, time and methods of supply the fertilization (fertigation) request. Drip irrigation system was used in this study established on both sides of the tree trunk at a distance of one meter. Each tree provided with two droppers (discharge $4 \mathrm{~L} / \mathrm{h}$ ) and the time of operation was 4 hours/day (32 L/tree/day) throughout the period of study. At the beginning of each season, the experimental trees which subjected to solid or interplanting conditions received $0.5 \mathrm{~kg}$ calcium super phosphate $\left(15.5 \% \mathrm{P}_{2} \mathrm{O}_{5}\right)$ per tree mixed with $10 \mathrm{~kg} /$ tree organic manure added in rounded trenches close to the root system around the tree canopy. In addition, nitrogen $(\mathrm{N})$ fertilizer was added at a rate of 178.5 and $357.0 \mathrm{~kg} \mathrm{~N}$ per ha as urea $(46.0 \% \mathrm{~N})$ divided by equal monthly doses from Feb. to Oct. under interplanting and solid conditions, respectively. Fertilizer of $\mathrm{K}$ was added at a rate of 238 kg K per ha as K sulfate (by three doses: March, June and October) under both interplanting and solid conditions. Moreover, micronutrients (Fe 500 ppm, Mn 250 ppm and Zn 250 ppm) were applied as foliar sprays 4 times/year, i.e. in April, June, August and October. Under interplanting and solid conditions, calcium super phosphate $\left(15.5 \% \mathrm{P}_{2} \mathrm{O}_{5}\right)$ was applied at a rate of 238 and $476 \mathrm{~kg}$ per ha during soil preparation, $\mathrm{N}$ fertilizer was added at a rate of 23.8 and $47.6 \mathrm{~kg}$ 
$\mathrm{N}$ per ha as urea $(46.0 \% \mathrm{~N})$ and $\mathrm{K}$ fertilizer was added at a rate of 59.5 and $119 \mathrm{~kg}$ K per ha as potassium sulfate, respectively, for soybean plants. Seeds of soybean variety Giza 22 were inoculated with Bradyrhizobium japonicum and Arabic gum was used as a sticking agent. It is important to mention that the biological $\mathrm{N}$ fixation by soybean should be considered, but in this experiment, there was no way to determine the amount of $\mathrm{N}$ derived from fixation and absorption from the soil.

Soybean plants were harvested on September $7^{\text {th }}$ and $10^{\text {th }}$ at 2018 and 2019 seasons, respectively. Meanwhile, mango fruits were harvested on August $13^{\text {th }}$ and $17^{\text {th }}$ at 2018 and 2019 seasons respectively. Also, orange fruits were harvested on November $3^{\text {rd }}$ and $7^{\text {th }}$ at 2018 and 2019 seasons, respectively. Moreover, mandarin fruits were harvested on November $14^{\text {th }}$ and $18^{\text {th }}$ at 2018 and 2019, respectively.

Parameters recorded

Soil carbon dioxide (CO2), organic carbon (OC) and $\mathrm{pH}$ in rhizosphere of orchard tree species

Sample of orchard tree species rhizosphere was taken after 60 days from soybean sowing to determine $\mathrm{OC}$ and $\mathrm{pH}$ [31] and the soil biological activity in terms $\mathrm{CO}_{2}$ as described by Gaur., et al. [33]. These analyses were determined by Soil, Water and Environment Research Institute, Giza, Egypt.

Orchards parameters: ten trees were measured in length at harvest to determine tree height $(\mathrm{cm})$. Also, samples of ten fruits per tree were collected from plot to determine some fruit traits; fruit weight (g), fruit volume $\left(\mathrm{cm}^{3}\right)$, fruit yield per tree $(\mathrm{kg})$ and fruit yield per ha (ton).

\section{Soybean parameters}

The following parameters were measured on ten plants at harvest from each plot: light intensity (lux) inside each canopy at the middle of the plant by Lux-meter apparatus at $12 \mathrm{~h}$ and expressed as percentage from light intensity measured above the plant, plant height $(\mathrm{cm})$, number of branches and pods per plant and seed yield per plant (g). Seed yield per ha (ton) were recorded on the basis of experimental sub plot area by harvesting all plants of each plot.

Competitive relationships

Land equivalent ratio (LER): LER is the ratio of area needed under sole cropping to one of interplanting at the same management level to produce an equivalent yield [34]. LER is calculated as fol- lows: $\mathrm{LER}=\left(\mathrm{Y}_{\mathrm{ab}} / \mathrm{Y}_{\mathrm{aa}}\right)+\left(\mathrm{Y}_{\mathrm{ba}} / \mathrm{Y}_{\mathrm{bb}}\right)$, where $\mathrm{Y}_{\mathrm{aa}}=$ Pure stand yield of crop a (orchards), $\mathrm{Y}_{\mathrm{bb}}=$ Pure stand yield of crop b (soybean), $\mathrm{Y}_{\mathrm{ab}}=$ Interplant yield of crop a (orchards) and $Y_{b a}=$ Interplant yield of crop b (soybean). RY was calculated as follows: RY of orchards = $\mathrm{Y}_{\mathrm{ab}} / \mathrm{Y}_{\mathrm{aa}} ; \mathrm{RY}$ of soybean $=\mathrm{Y}_{\mathrm{ba}} / \mathrm{Y}_{\mathrm{bb}}$, where RY of orchards and RY of soybean are relative yields of orchards and soybean, respectively.

Land equivalent coefficient (LEC): LEC is a measure of interaction concerned with the strength of relationship [35]. It is calculated as follows: $L E C=L_{a} \times L_{b}$, where $L_{a}=$ relative yield of crop a (orchards) and $\mathrm{L}_{\mathrm{b}}=$ relative yield of crop $\mathrm{b}$ (soybean).

\section{Economic return (USD per ha)}

Total return per ha: Total return per ha was calculated by plus income of orchards fruits per ha (USD) with income of soybean seeds per ha (USD).

Monetary advantage index (MAI): MAI suggests that the economic assessment should be in terms of the value of land saved; this could probably be most assessed on the basis of the rentable value of this land. MAI was calculated according to the formula, suggested by Willey [36]. MAI= [Value of combined intercrops $\mathrm{x}$ (LER-1)]/LER. Market prices of orchards were 1000, 333 and 333 USD per ton for mango, orange and mandarin fruits, respectively, and 450 USD per ton for soybean seeds.

\section{Statistical analysis}

Analysis of variance of the obtained results of each season was performed. The measured variables were analyzed by ANOVA using MSTATC statistical package [37]. Mean comparisons were performed using the least significant differences (L.S.D) test with a significance level of 5\% [38].

\section{Results and Discussion}

Soil $\mathrm{CO}_{2}, \mathrm{OC}$ and $\mathrm{pH}$ in rhizosphere of orchard tree species Orchard tree species

Soil $\mathrm{CO}_{2}$, OC and $\mathrm{pH}$ affected significantly by orchard tree species (Table 2). With respect to soil $\mathrm{CO}_{2}$, the rhizosphere of the roots of mandarin trees had higher $\mathrm{CO}_{2}$, meanwhile the reverse was true for mango trees under interplanting conditions. It recorded 95.92, 108.32 and $111.63 \mathrm{mg} / 100 \mathrm{~g}$ soil for mango, orange and mandarin trees rhizosphere, respectively. With respect to soil OC, interplanted mango trees had lower OC $(810 \mathrm{mg} / 100 \mathrm{~g}$ soil $)$ in the rhizo- 
Interplanting Soybean with Three Species of Orchard Trees Under Two Soybean Plant Distributions in Sandy Soils

\begin{tabular}{|c|c|c|c|c|}
\hline Treatments & Soybean plant distribution & $\mathrm{CO}_{2}(\mathrm{mg} / 100 \mathrm{~g}$ soil $)$ & OC (mg/100 g soil ) & pH \\
\hline \multirow[t]{3}{*}{ Soybean + Orange } & Narrow distribution & 103.71 & 880 & 7.90 \\
\hline & Wide distribution & 112.94 & 970 & 7.95 \\
\hline & Mean & 108.32 & 920 & 7.92 \\
\hline \multirow[t]{3}{*}{ Soybean + Mandarin } & Narrow distribution & 107.18 & 940 & 7.85 \\
\hline & Wide distribution & 116.09 & 1050 & 7.88 \\
\hline & Mean & 111.63 & 995 & 7.86 \\
\hline \multirow[t]{3}{*}{ Soybean + Mango } & Narrow distribution & 98.22 & 840 & 8.02 \\
\hline & Wide distribution & 93.63 & 780 & 8.04 \\
\hline & Mean & 95.92 & 810 & 8.02 \\
\hline \multirow{2}{*}{$\begin{array}{l}\text { Average of soybean plant } \\
\text { distribution }\end{array}$} & Narrow distribution & 103.03 & 880 & 7.92 \\
\hline & Wide distribution & 107.55 & 933 & 7.95 \\
\hline \multicolumn{2}{|c|}{ L.S.D. at $5 \%$ Orchard tree specie } & 6.69 & 90.30 & 0.10 \\
\hline \multicolumn{2}{|c|}{ F-test at $5 \%$ Soybean plant distribution } & $*$ & * & N.S. \\
\hline \multicolumn{2}{|c|}{ L.S.D. at $5 \%$ Interaction } & 7.03 & 93.55 & N.S. \\
\hline
\end{tabular}

Table 2: Soil $\mathrm{CO}_{2}, \mathrm{OC}$ and $\mathrm{pH}$ in rhizosphere of orchard tree species under interplanting conditions.

sphere of their roots, meanwhile the rhizosphere of the soybean + mandarin system had the opposite trend ( $995 \mathrm{mg} / 100 \mathrm{~g}$ soil). With regard to soil $\mathrm{pH}$ values, the rhizosphere of the soybean + mango system had higher $\mathrm{pH}$ (8.02), meanwhile the rhizosphere of the interplanted orange trees had the opposite trend (7.86). It is worthy to note that there were no significant differences between orange and mandarin trees for soil $\mathrm{CO}_{2}, \mathrm{OC}$ and $\mathrm{pH}$ in their rhizosphere under interplanting conditions. These results could be due to the amount of soil $\mathrm{CO}_{2}$ that formed in the rhizosphere of orchard tree species was differed by inter-specific competition between orchards and soybean for basic growth resources under interplanting conditions. Consequently, it is expected that higher soil $\mathrm{CO}_{2}$ altered under-ground interactions in citrus trees rhizosphere which have an important role in the advantage effect of interplanting than those of mango rhizosphere. The $\mathrm{pH}$ value of soil water is in the range of $4.5-8.3$ and it is mainly given by the equilibrium between free and bound $\mathrm{CO}_{2}$ [39]. Accordingly, it is likely that changes in soil OC influenced strongly soil $\mathrm{N}$ turnover by aggregate stability and soil porosity because of the importance of available carbon for microbial immobilization. It is expected that soil OC improved soil quality through its extensive impacts on soil physical, chemical and biological properties. It seems that canopy architecture of citrus furnished more suitable environmental conditions for enhanced soybean photosynthetic process than those of mango trees which reflected on the high energy of metabolism, zymotic $\mathrm{N}$ and other nutrient elements for microorganism's activity [40]. These results are similar to those obtained by Yost and Hartemink [22] who reported that soil OC increased the cation exchange capacity and lowered the bulk density in sandy soils.

\section{Soybean plant distributions}

Soil $\mathrm{CO}_{2}$ and OC affected significantly by soybean plant distributions, meanwhile soil $\mathrm{pH}$ was not affected under sandy soil conditions (Table 2). With respect to soil $\mathrm{CO}_{2}$, growing two soybean plants distanced at $50 \mathrm{~cm}$ between hills gave higher $\mathrm{CO}_{2}(107.55$ $\mathrm{mg} / 100 \mathrm{~g}$ soil) in the rhizosphere of the soybean roots than the narrow one (103.03 mg/100 g soil). Wide soybean plant distribution (two soybean rows per ridge) increased soil $\mathrm{CO}_{2}$ in the rhizosphere of the soybean roots by $4.38 \%$ compared with the other one.

With respect soil OC, growing two soybean plants distanced at $50 \mathrm{~cm}$ between hills gave higher OC (933 mg/100 g soil) in the rhizosphere of the soybean roots than the narrow one $(880 \mathrm{mg} / 100$ g soil). Wide soybean plant distribution (two soybean rows per ridge) increased soil OC in the rhizosphere of the soybean roots by $6.02 \%$ compared with the other one. 
These results probably attributed to wide soybean plant distribution (two rows per ridge) decreased intra-specific competition between soybean plants and each other for basic growth resources than those that grow in one row per ridge. Certainly, soil health is influenced by agricultural management [41]. Increased light intensity improved the morphological parameters, carbon assimilation rate (production of sucrose and starch) and enzymatic activities [42], and thereby it is expected that this biological situation will balance carbon level in the soybean plant as a result of the net photosynthetic rate.

Interaction between orchard tree species and soybean plant distributions

Soil $\mathrm{CO}_{2}$ and $\mathrm{OC}$ affected significantly by orchard tree species $\mathrm{x}$ soybean plant distributions interaction, meanwhile soil $\mathrm{pH}$ was not affected (Table 2). Growing two soybean plants distanced at 50 $\mathrm{cm}$ between hills (two soybean rows per ridge) recorded higher soil $\mathrm{CO}_{2}$ and $\mathrm{OC}$ in the rhizosphere of the soybean + mandarin system compared with the other treatments. It is worthy to note that there were no significant differences between the interplanting systems soybean + mandarin and soybean + orange for soil $\mathrm{CO}_{2}$ and OC. These results may be due to the canopy structure of mandarin trees that integrated positively with soybean plants of wide distribution to reduce intra and inter-specific competition between the same and different species, respectively for climatic and edaphic environmental conditions compared with the other treatments. So, it may be possible that interplanting soybean that distanced at 50 $\mathrm{cm}$ between hills with mandarin trees led to complementary interactions between the root systems, such as $\mathrm{N}$ transfer or complementary use of different nutrients. It is important to mention that the amount of soil $\mathrm{CO}_{2}$ and $\mathrm{OC}$ was constant between narrow and wide soybean plant distributions in the rhizosphere of mango trees (Table 2) probably due to soybean growth and development suffered from unfavorable environmental conditions that resulted from bigger canopy structure of mango trees. The interactions between the trees and intercropping at proximity include the competition for other resources such as moisture and soil nutrients, or positive interactions by improving soil quality and nutrients availability [43]. These data show that each of these two factors act dependently on soil $\mathrm{CO}_{2}$ and OC.

\section{Yield traits}

\section{Orchard tree species}

With respect to orange trees, fruit weight, fruit yields per tree, and per ha were affected significantly by soybean plant distributions in both seasons, meanwhile, tree height and fruit volume were not affected under interplanting conditions (Table 3). Growing two soybean plants distanced at $50 \mathrm{~cm}$ between hills (two soybean rows per ridge) increased fruit weight of orange by 1.10 and $1.38 \%$, fruit yield per tree by 9.14 and $8.23 \%$ and fruit yield per ha by 10.23 and $10.06 \%$ in the first and second seasons, respectively than the narrow one. These results were due to wide soybean plant distribution that improved the translocation of soil water and nutrients between root and leaves of the orange tree as a result of increasing $\mathrm{OC}$ that resulted from increased soil $\mathrm{CO}_{2}$ (Table 2) in the rhizosphere of orange trees. About $99 \%$ of $\mathrm{CO}_{2}$ is dissolved in water in a molecular form, only about $1 \%$ reacts with $\mathrm{H}_{2} \mathrm{O}$ [39]. These results are in accordance with those obtained by Idso and Kimball [44] who showed that there was a positive response of sour orange seedlings and trees to increased $\mathrm{CO}_{2}$ level, which improved the biomass growth of trees to 2.3-fold for fine root mass and 2-fold more branches, 1.75-fold of leaves, trunk and branch volume bigger to 2.6 fold.

\begin{tabular}{|c|c|c|c|c|c|c|}
\hline Treatments & Soybean plant distribution & $\begin{array}{c}\text { Tree height } \\
\text { (cm) }\end{array}$ & \begin{tabular}{|c} 
Fruit weight \\
(g)
\end{tabular} & $\begin{array}{c}\text { Fruit volume } \\
\left(\mathrm{cm}^{3}\right)\end{array}$ & $\begin{array}{c}\text { Fruit yield/tree } \\
\text { (kg) }\end{array}$ & $\begin{array}{c}\text { Fruit yield/ha } \\
\text { (ton) }\end{array}$ \\
\hline \multicolumn{2}{|c|}{ Growing season } & \multicolumn{5}{|c|}{2018 season } \\
\hline \multirow[t]{2}{*}{ Soybean + Orange } & Narrow distribution & 172.63 & 215.83 & 207.13 & 6.34 & 2.54 \\
\hline & Wide distribution & 171.11 & 218.22 & 208.95 & 6.92 & 2.80 \\
\hline \multicolumn{2}{|l|}{ F-test at $5 \%$} & N.S. & $*$ & N.S. & $*$ & $*$ \\
\hline \multicolumn{2}{|c|}{ Solid culture of orange } & & & & & 2.51 \\
\hline \multicolumn{2}{|l|}{ Growing season } & \multicolumn{5}{|c|}{2019 season } \\
\hline \multirow[t]{2}{*}{ Soybean + Orange } & Narrow distribution & 178.19 & 217.64 & 211.29 & 7.04 & 2.88 \\
\hline & Wide distribution & 176.47 & 220.65 & 211.87 & 7.62 & 3.07 \\
\hline \multicolumn{2}{|c|}{ F-test at $5 \%$} & N.S. & $*$ & N.S. & $*$ & * \\
\hline \multicolumn{2}{|c|}{ Solid culture of orange } & & & & & 2.80 \\
\hline
\end{tabular}

Table 3: Yield traits of orange trees as affected by two soybean plant distributions under interplanting conditions (2018 and 2019 seasons). 
With regard to mandarin trees, fruit weight, and volume, as well as fruit yields per tree and per ha were affected significantly by soybean plant distributions in both seasons, meanwhile tree height was not affected under interplanting conditions (Table 4).
Growing two soybean plants distanced at $50 \mathrm{~cm}$ between hills increased fruit weight by 9.94 and $6.31 \%$, fruit volume by 13.90 and $11.98 \%$, fruit yield per tree by 7.24 and $6.58 \%$ and fruit yield per ha by 7.49 and $6.29 \%$ in the first and second seasons, respectively,

\begin{tabular}{|c|c|c|c|c|c|c|}
\hline Treatments & $\begin{array}{c}\text { Soybean plant } \\
\text { distribution }\end{array}$ & $\begin{array}{c}\text { Tree height } \\
\text { (cm) }\end{array}$ & $\begin{array}{l}\text { Fruit weight } \\
\text { (g) }\end{array}$ & $\begin{array}{l}\text { Fruit volume } \\
\qquad\left(\mathrm{cm}^{3}\right)\end{array}$ & $\begin{array}{l}\text { Fruit yield/tree } \\
\text { (kg) }\end{array}$ & $\begin{array}{c}\text { Fruit yield/ha } \\
\text { (ton) }\end{array}$ \\
\hline \multicolumn{2}{|c|}{ Growing season } & \multicolumn{5}{|c|}{2018 season } \\
\hline \multirow[t]{2}{*}{ Soybean + Mandarin } & Narrow distribution & 147.73 & 42.65 & 15.32 & 9.38 & 7.34 \\
\hline & Wide distribution & 146.22 & 46.89 & 17.45 & 10.06 & 7.89 \\
\hline \multicolumn{2}{|l|}{ F-test at 5\% } & N.S. & $*$ & $*$ & $*$ & $*$ \\
\hline \multicolumn{2}{|c|}{ Solid culture of mandarin } & & & & & 7.27 \\
\hline \multicolumn{2}{|c|}{ Growing season } & \multicolumn{5}{|c|}{2019 season } \\
\hline \multirow[t]{2}{*}{ Soybean + Mandarin } & Narrow distribution & 151.23 & 42.93 & 15.44 & 9.87 & 7.62 \\
\hline & Wide distribution & 153.02 & 45.64 & 17.29 & 10.52 & 8.10 \\
\hline \multicolumn{2}{|c|}{ F-test at 5\% } & N.S. & $*$ & $*$ & $*$ & $*$ \\
\hline \multicolumn{2}{|c|}{ Solid culture of mandarin } & & & & & 7.63 \\
\hline
\end{tabular}

Table 4: Yield traits of mandarin trees as affected by two soybean plant distributions under interplanting conditions (2018 and 2019 seasons).

than the narrow one. It is obvious that the wide soybean plant distribution provided the mandarin trees with the required quantities of $\mathrm{CO}_{2}$ and $\mathrm{OC}$ than the narrow one. With respect to mango trees, tree height, fruit weight and volume, fruit yields per tree and per ha were not affected by soybean plant distributions in both seasons under interplanting conditions (Table 5). These results may be attributed to soybean plant distributions that gave the same amount of $\mathrm{CO}_{2}$ and $\mathrm{OC}$ in the rhizosphere of mango trees under interplanting conditions (Table 2). Consequently, it is expected that carbonic anhydrase enzyme in interplanted mango trees tissues will catalyze the conversion of soil $\mathrm{CO}_{2}$ and water to carbonic acid, the electrons extracted from the water will give rise to the ATP and NADPH needed to reduce $\mathrm{CO}_{2}$ to sugars [45]. The dedication of significant carbon resources that legumes make to their rhizospheres in the form of organic acids, root, and nodule biomass or nutrient uptake mechanisms benefits the roots of intercropped plants often even more than the legume itself [46]. Accordingly, this biological situation led to the stability of dry matter accumulation in the sink (fruits) during fruit development under two soybean plant distributions. These results are in agreement with those obtained by Bhat., et al. [47] who reported that leguminous crops increased the absorptive capacity of water and nutrient in upper fertile layers of soils thereby reducing evaporation.

\begin{tabular}{|c|c|c|c|c|c|c|}
\hline Treatments & $\begin{array}{l}\text { Soybean plant } \\
\text { distribution }\end{array}$ & $\begin{array}{l}\text { Tree height } \\
\text { (cm) }\end{array}$ & Fruit weight (g) & Fruit volume $\left(\mathrm{cm}^{3}\right)$ & Fruit yield/tree $(\mathrm{kg})$ & Fruit yield/ha (ton) \\
\hline \multicolumn{2}{|c|}{ Growing season } & \multicolumn{5}{|c|}{2018 season } \\
\hline \multirow{2}{*}{$\begin{array}{c}\text { Soybean + } \\
\text { Mango }\end{array}$} & Narrow distribution & 215.62 & 287.04 & 291.62 & 11.63 & 9.22 \\
\hline & Wide distribution & 214.18 & 289.83 & 290.11 & 11.76 & 9.30 \\
\hline \multicolumn{2}{|c|}{ F-test at $5 \%$} & N.S. & N.S. & N.S. & N.S. & N.S. \\
\hline \multicolumn{2}{|c|}{ Solid culture of mango } & & & & & 9.26 \\
\hline \multicolumn{2}{|c|}{ Growing season } & \multicolumn{5}{|c|}{2019 season } \\
\hline \multirow{2}{*}{$\begin{array}{c}\text { Soybean + } \\
\text { Mango }\end{array}$} & Narrow distribution & 216.87 & 303.65 & 305.44 & 11.85 & 9.57 \\
\hline & Wide distribution & 218.51 & 301.87 & 306.71 & 11.98 & 9.59 \\
\hline \multicolumn{2}{|c|}{ F-test at $5 \%$} & N.S. & N.S. & N.S. & N.S. & N.S. \\
\hline \multicolumn{2}{|c|}{ Solid culture of mango } & & & & & 9.58 \\
\hline
\end{tabular}

Table 5: Yield traits of mango trees as affected by two soybean plant distributions under interplanting conditions (2018 and 2019 seasons). 
Interplanting Soybean with Three Species of Orchard Trees Under Two Soybean Plant Distributions in Sandy Soils

Soybean plant

Orchard tree species

Percentage of light intensity at the middle of the soybean plant, plant height, number of branches and pods per plant, as well as seed yields per plant and per ha were affected significantly by orchard tree species in both seasons (Table 6 and 7). Interplanting soybean with mandarin trees recorded higher light intensity at the middle of the plant, the number of branches and pods per plant, as well as seed yields per plant and per ha than the other interplanting systems soybean + orange and soybean + mango in both seasons. Interplanting soybean with mandarin trees increased light intensity in the middle of soybean plant by about $1.00 \%$ in both seasons than those of soybean + orange system.

\begin{tabular}{|c|c|c|c|c|}
\hline Treatments & $\begin{array}{l}\text { Soybean plant } \\
\text { distribution }\end{array}$ & $\begin{array}{l}\text { Percentage of light intensity } \\
\text { (lux) at middle of the plant }\end{array}$ & $\begin{array}{l}\text { Plant height } \\
\text { (cm) }\end{array}$ & Number of branches per plant \\
\hline \multirow[t]{3}{*}{ Soybean + Orange } & Narrow distribution & 9.89 & 108.34 & 2.67 \\
\hline & Wide distribution & 10.03 & 107.19 & 2.80 \\
\hline & Mean & 9.96 & 107.76 & 2.73 \\
\hline \multirow[t]{3}{*}{ Soybean + Mandarin } & Narrow distribution & 9.97 & 107.76 & 2.72 \\
\hline & Wide distribution & 10.13 & 106.53 & 2.89 \\
\hline & Mean & 10.05 & 107.14 & 2.80 \\
\hline \multirow[t]{3}{*}{ Soybean + Mango } & Narrow distribution & 8.72 & 110.56 & 2.55 \\
\hline & Wide distribution & 8.76 & 110.23 & 2.50 \\
\hline & Mean & 8.74 & 110.39 & 2.52 \\
\hline \multirow{2}{*}{$\begin{array}{l}\text { Average of soybean plant } \\
\text { distribution }\end{array}$} & Narrow distribution & 9.52 & 108.88 & 2.64 \\
\hline & Wide distribution & 9.64 & 107.98 & 2.73 \\
\hline \multicolumn{2}{|c|}{ L.S.D. at 5\% Orchard tree specie } & & 0.93 & 0.09 \\
\hline \multicolumn{2}{|c|}{ F-test at $5 \%$ Soybean plant distribution } & $*$ & $*$ & $*$ \\
\hline \multicolumn{2}{|l|}{ L.S.D. at $5 \%$ Interaction } & 0.14 & 1.04 & 0.12 \\
\hline Treatments & $\begin{array}{c}\text { Soybean plant } \\
\text { distribution }\end{array}$ & Number of pods per plant & $\begin{array}{l}\text { Seed yield per } \\
\text { plant }(\mathrm{g})\end{array}$ & Seed yield per ha (ton) \\
\hline \multirow[t]{3}{*}{ Soybean + Orange } & Narrow distribution & 36.68 & 8.78 & 1.29 \\
\hline & Wide distribution & 36.94 & 9.08 & 1.37 \\
\hline & Mean & 36.81 & 8.93 & 1.33 \\
\hline \multirow[t]{3}{*}{ Soybean + Mandarin } & Narrow distribution & 36.83 & 8.97 & 1.32 \\
\hline & Wide distribution & 37.23 & 9.30 & 1.44 \\
\hline & Mean & 37.03 & 9.13 & 1.38 \\
\hline \multirow[t]{3}{*}{ Soybean + Mango } & Narrow distribution & 34.10 & 8.41 & 1.14 \\
\hline & Wide distribution & 34.18 & 8.47 & 1.17 \\
\hline & Mean & 34.14 & 8.44 & 1.15 \\
\hline \multirow{2}{*}{$\begin{array}{l}\text { Average of soybean plant } \\
\text { distribution }\end{array}$} & Narrow distribution & 35.87 & 8.72 & 1.25 \\
\hline & Wide distribution & 36.11 & 8.95 & 1.32 \\
\hline \multicolumn{2}{|c|}{ L.S.D. at $5 \%$ Orchard tree specie } & 0.25 & 0.23 & 0.11 \\
\hline \multicolumn{2}{|c|}{ F-test at $5 \%$ Soybean plant distribution } & $*$ & $*$ & $*$ \\
\hline \multicolumn{2}{|l|}{ L.S.D. at $5 \%$ Interaction } & 0.32 & 0.29 & 0.16 \\
\hline \multicolumn{2}{|l|}{ Solid culture of soybean } & & & 3.19 \\
\hline
\end{tabular}

Table 6: Soybean seed yield and its attributes as affected by orchard tree species, soybean plant distributions and their interaction in the first season. 
Interplanting Soybean with Three Species of Orchard Trees Under Two Soybean Plant Distributions in Sandy Soils

\begin{tabular}{|c|c|c|c|c|}
\hline Treatments & $\begin{array}{c}\text { Soybean plant distribu- } \\
\text { tion }\end{array}$ & $\begin{array}{l}\text { Percentage of light intensity } \\
\text { (lux) at middle of the plant }\end{array}$ & Plant height (cm) & $\begin{array}{c}\text { Number of } \\
\text { branches per plant }\end{array}$ \\
\hline \multirow[t]{3}{*}{ Soybean + Orange } & Narrow distribution & 10.00 & 106.11 & 2.81 \\
\hline & Wide distribution & 10.26 & 104.89 & 2.96 \\
\hline & Mean & 10.13 & 105.50 & 2.88 \\
\hline \multirow[t]{3}{*}{ Soybean + Mandarin } & Narrow distribution & 10.18 & 105.61 & 2.88 \\
\hline & Wide distribution & 10.29 & 104.23 & 3.02 \\
\hline & Mean & 10.23 & 104.92 & 2.95 \\
\hline \multirow[t]{3}{*}{ Soybean + Mango } & Narrow distribution & 8.98 & 108.49 & 2.67 \\
\hline & Wide distribution & 9.03 & 108.32 & 2.63 \\
\hline & Mean & 9.00 & 108.40 & 2.65 \\
\hline \multirow{2}{*}{$\begin{array}{l}\text { Average of soybean plant } \\
\text { distribution }\end{array}$} & Narrow distribution & 9.72 & 106.73 & 2.78 \\
\hline & Wide distribution & 9.86 & 105.81 & 2.87 \\
\hline \multicolumn{2}{|c|}{$\begin{array}{l}\text { L.S.D. at } 5 \% \text { Orchard tree specie } \\
\text { F-test at } 5 \% \text { Soybean plant distribution } \\
\text { L.S.D. at } 5 \% \text { Interaction }\end{array}$} & $\begin{array}{c}0.12 \\
* \\
0.17\end{array}$ & $\begin{array}{c}0.97 \\
* \\
1.12 \\
\end{array}$ & $\begin{array}{c}0.11 \\
* \\
0.15\end{array}$ \\
\hline Treatments & $\begin{array}{c}\text { Soybean plant } \\
\text { distribution }\end{array}$ & Number of pods per plant & $\begin{array}{c}\text { Seed yield per plant } \\
\text { (g) }\end{array}$ & $\begin{array}{l}\text { Seed yield per ha } \\
\text { (ton) }\end{array}$ \\
\hline \multirow{3}{*}{$\begin{array}{l}\text { Soybean + Orange } \\
\text { Wide distributio } \\
\text { Mean }\end{array}$} & Narrow distribution & 37.03 & 8.92 & 1.32 \\
\hline & 37.51 & 9.27 & 1.51 & \\
\hline & 37.27 & 9.09 & 1.41 & \\
\hline \multirow[t]{3}{*}{ Soybean + Mandarin } & Narrow distribution & 37.22 & 9.06 & 1.36 \\
\hline & 37.72 & 9.41 & 1.54 & \\
\hline & 37.47 & 9.23 & 1.45 & \\
\hline \multirow[t]{3}{*}{ Soybean + Mango } & Narrow distribution & 35.43 & 8.52 & 1.17 \\
\hline & 35.42 & 8.54 & 1.18 & \\
\hline & 35.42 & 8.53 & 1.16 & \\
\hline \multirow{2}{*}{$\begin{array}{l}\text { Average of soybean plant } \\
\text { distribution } \\
\text { Wide distribution }\end{array}$} & Narrow distribution & 36.56 & 8.83 & 1.28 \\
\hline & 36.88 & 9.07 & 1.41 & \\
\hline \multicolumn{2}{|c|}{$\begin{array}{l}\text { L.S.D. at } 5 \% \text { Orchard tree specie } \\
\text { F-test at } 5 \% \text { Soybean plant distribution } \\
\text { L.S.D. at } 5 \% \text { Interaction }\end{array}$} & $\begin{array}{l}0.29 \\
* \\
0.36\end{array}$ & $\begin{array}{l}0.27 \\
* \\
0.33\end{array}$ & $\begin{array}{l}0.14 \\
* \\
0.18\end{array}$ \\
\hline \multicolumn{2}{|l|}{ Solid culture of soybean } & & & 3.23 \\
\hline
\end{tabular}

Table 7: Soybean seed yield and its attributes as affected by orchard tree species, soybean plant distributions and their interaction in the second season.

Meanwhile, light intensity at the middle of soybean plant was increased by 14.98 and $13.66 \%$ in the first and second seasons, respectively, in interplanting soybean with mandarin trees than those interplanted with mango trees.

These results may be due to the canopy architecture of mango trees that did not allow the passage of more light into soybean canopy than those of citrus trees under interplanting conditions. It is worthy to note that there were no significant differences between the interplanting systems soybean + mandarin and soybean + orange for the percentage of light intensity at the middle of soybean plant in the second season.

Conversely, interplanting soybean with mandarin trees decreased plant height of soybean by $0.05 \%$ in both seasons than those of soybean + orange system. Meanwhile, soybean + mandarin 
system decreased plant height by 2.94 and $3.21 \%$ in the first and second seasons, respectively, than those interplanted with mango trees. It is important to mention that there were no significant differences between the interplanting systems soybean + mandarin and soybean + orange for plant height in both seasons. The observed response in plant height of soybean that interplanted with mango trees may be primarily attributed to an increase of internodes number and elongation of soybean plant. Mutual shading is known to increase the proportion of invisible radiation, which has a specific elongating effect upon plants [48]. With respect to the number of branches per plant, interplanting soybean with mandarin trees increased the number of branches per plant by 2.56 and $2.43 \%$ in the first and second seasons, respectively, than those of soybean + orange system. Meanwhile, the number of branches per plant was increased by 11.11 and $11.32 \%$ in interplanting soybean with mandarin in the first and second seasons, respectively, than those of soybean + mango system. There were no significant differences between the interplanting systems soybean + mandarin and soybean + orange for the number of branches per plant in both seasons.

With regard to the number of pods per plant, interplanting soybean with mandarin trees increased the number of pods per plant by $0.05 \%$ in both seasons than those interplanted with orange trees. Meanwhile, the number of pods per plant was increased by 8.46 and $5.78 \%$ in the first and second seasons, respectively, in interplanting soybean with mandarin trees than those interplanted with mango trees. It is worthy to note that there were no significant differences between the interplanting systems soybean + mandarin and soybean + orange for the number of pods per plant in both seasons. Also, seed yield per plant was increased by 2.23 and $1.54 \%$ in the first and second seasons, respectively, in the soybean + mandarin system than those interplanted with orange trees. Meanwhile, seed yield per plant was increased by 8.17 and $8.20 \%$ in the first and second seasons, respectively, in the soybean + mandarin system than those interplanted with mango trees. These results could be due to canopy architecture of mandarin that played a major role in increase more solar radiation penetration to adjacent soybean plants and consequently great efficiency in the photosynthetic process of soybean which reflected finally on seed yield per plant. There were no significant differences between the interplanting systems soybean + mandarin and soybean + orange for number of seeds per plant in both seasons. Low light levels available for shaded soybean plants might have caused a restriction of their genetic potential resulting in the modification of their growth pattern [49].
Furthermore, soybean + mandarin increased seed yield per ha by 3.75 and $2.83 \%$ in the first and second seasons, respectively, than those of soybean + orange system. Meanwhile, soybean + mandarin increased seed yield per ha by 20.00 and $25.00 \%$ in the first and second seasons, respectively, than those of soybean + mango. These results may be attributed to canopy structure of soybean variety Giza 22 that integrated with canopy structure of mandarin reduced inter and intra-specific competition between the two species and the same species, respectively, for basic growth resources. It is important to mention that there were no significant differences between the interplanting systems soybean + mandarin and soybean + orange for the number of seeds per ha in both seasons. These results are in harmony with those obtained by Selim., et al. [28] who revealed that interplanting soybean with mandarin trees decreased soybean seed yield and its attributes compared with soybean solid culture in both seasons.

\section{Soybean plant distributions}

Percentage of light intensity at the middle of the soybean plant, plant height, number of branches and pods per plant, as well as seed yields per plant and per ha were affected significantly by soybean plant distributions in both seasons under sandy soil conditions (Table 6 and 7). Wide soybean plant distribution had higher light intensity at the middle of the plant, the number of branches and pods per plant, as well as seed yields per plant and per ha than those of the narrow one in both seasons. Growing two soybean plants distanced at $50 \mathrm{~cm}$ between hills (two soybean rows per ridge) increased light intensity in the middle of the plant and by 1.26 and $1.44 \%$ in the first and second seasons, respectively, than the narrow one. These results may be due to wide soybean plant distribution (two rows per ridge) that decreased intra-specific competition between soybean plants and each other for basic growth resources especially light penetration which reflected on higher solar radiation penetration and transmission within the canopies of soybean plants than those that distanced at $25 \mathrm{~cm}$ between hills (Figure 1).

Consequently, it is expected that the favorable soil condition that formed by wide soybean plant distribution will result in better root development thereby enabling soybean plants to uptake more soil moisture and nutrients than those of the narrow one. Accordingly, it is likely that this positive effect will enhance the source capacity of soybean to intercept more solar radiation under sandy soil conditions. These results are in accordance with those 


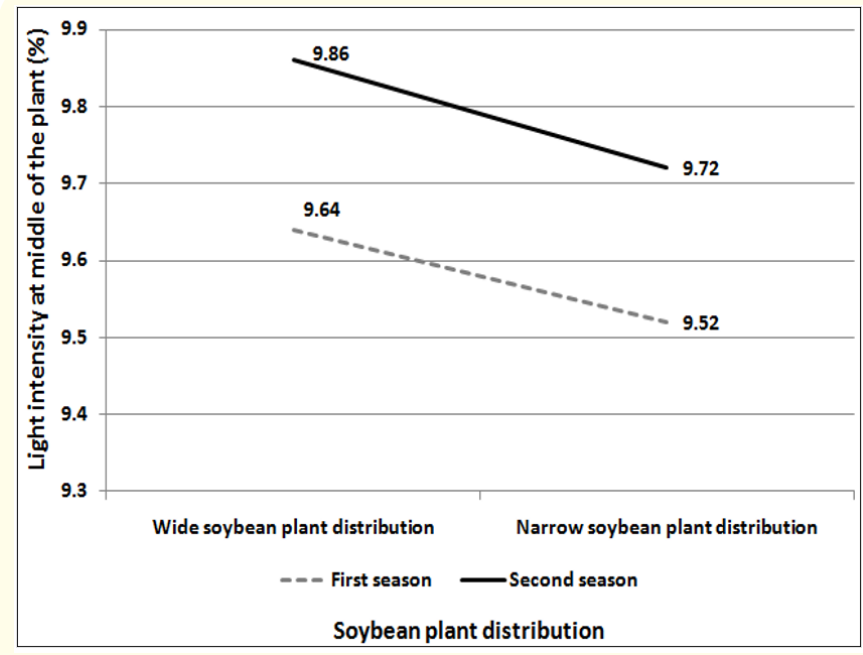

Figure 1: Light intensity at middle of the plant under two soybean plant distributions.

obtained by Cox and Cherney [50] who reported that row spacing had a greater effect on yield than seeding rate.

However, growing two soybean plants distanced at $50 \mathrm{~cm}$ between hills (two soybean rows per ridge) decreased soybean plant height by about $1.00 \%$ in both seasons than the narrow one. These results could be primarily attributed to an increase of internodes number and elongation of the soybean plant as a result of increasing plant hormones under sandy soil conditions. Accordingly, it is expected that there was more shading around soybean plants of narrow distribution that suffered from mutual shading compared to those of wide distribution. With respect to the number of branches per plant, it was increased by 3.40 and $3.23 \%$ in the first and second seasons, respectively when grown in wide distribution than the narrow one. These results probably due to wide plant distribution of soybean that furnished better above-ground conditions especially light intensity for the increasing number of branches per plant during growth and development stages than those of the narrow one. Moreover, wide soybean plant distribution increased the number of pods per plant by about $1.00 \%$ in both seasons than the narrow one. These results could be related to the proportion of solar radiation that reached soybean plants which reflected positively on the number of branches per plant under wide distribution during the growth and development of soybean. With regard to seed yield per plant, it was increased by 2.63 and $2.71 \%$ in the first and second seasons, respectively under wide distribution than the narrow one. These results probably attributed to the increments in the number of branches and pods of the soybean plants that distanced at $50 \mathrm{~cm}$ between hills than the narrow one. Furthermore, wide soybean plant distribution increased seed yield per ha by 5.60 and $10.15 \%$ in the first and second seasons, respectively than the narrow one. These results are in the same context as those obtained by Akond., et al. [51] who mentioned that soybean has the capacity to compensate space in the canopy and maintain yield can be seen as the probable hypothesis to explain this behavior.

Interaction between orchard tree species and soybean plant distributions

Percentage of light intensity at the middle of the soybean plant, plant height, number of branches and pods per plant, as well as seed yields per plant and per ha were affected significantly by orchard tree species $\mathrm{x}$ soybean plant distributions interaction in both seasons (Table 6 and 7). Soybean plants of wide distribution in soybean + mandarin system had the highest light intensity at the middle of the plant, the number of branches and pods per plant, as well as seed yields per plant and per ha compared with the other treatments in both seasons. These results may be attributed to the canopy structure and root system of mandarin trees that were more compatible with those of soybean plants of wide distribution to tolerate the negative effects of interplanting conditions. It is important to mention that there were no significant differences between wide plant distribution of soybean + mandarin system and wide plant distribution of soybean + orange system for seed yield per ha, indicating canopy structure and root system of citrus trees were more compatible for growing two soybean plants distanced at $50 \mathrm{~cm}$ between hills (two soybean rows per ridge) than those of mango trees under interplanting conditions. Hence, the state of nutrition, size, and yield of citrus are closely related to the amount of soil explored by the root system [52]. However, there were no significant differences between narrow and wide soybean plant distributions for seed yield traits in the soybean + mango system probably due to stability in the amount of soil $\mathrm{CO}_{2}$ and $\mathrm{OC}$ in the rhizosphere of the soybean + mango system (Table 2). Carbonate solubility is closely related to $\mathrm{CO}_{2}$ production which is determined by biological activity in the soil [53]. Canopy structure of mango trees is likely to play a basic role in shading soybean plants regardless of soybean plant distribution. These data show that citrus trees responded differently to soybean plant distributions for the percentage of light intensity at the middle of the soybean plant, plant height, the number of branches and pods per plant, as well as seed yields per plant and per ha. Meanwhile, mango trees responded similarly to soybean plant distributions for all the studied soybean traits. 


\section{Competitive relationships}

Land equivalent ratio (LER)

The values of land equivalent ratio (LER) were estimated by using data of recommended solid cultures of both crops. LER of more than 1.00 indicates yield advantage, equal to 1.00 indicates no gain or no loss and less than 1.00 indicates yield loss [54]. It can be used both for replacement and additives series of interplanting. The results obtained strongly coincided with the definition of LER. LER values were greater than one for all treatments in both seasons (Table 8). LER ranged from 1.34 by growing two soybean plants distanced at $25 \mathrm{~cm}$ between hills with mango trees to 1.53 by growing two soybean plants distanced at $50 \mathrm{~cm}$ between hills with citrus trees in the first season. Also, LER ranged from 1.35 by growing soybean in narrow distribution with mango trees to 1.52 by growing soybean in wide distribution with citrus trees in the second one. LER of 1.53 indicates that the planted area to solid cultures would need to be $53 \%$ greater than the planted area to interplant to produce the same combined yields (i.e. 50\% more land would be required as a solid crop to produce the same yield as interplanting). The advantage of the highest LER by growing two soybean plants distanced at $50 \mathrm{~cm}$ between hills (two soybean rows per ridge) with citrus trees probably due to the reduction in inter and intra-specific competition between different and same species, respectively, for available growth resources compared with the other treatments. These results are in the same context with Selim., et al. [28] who showed that LER values were greater than one for all soybean varieties under interplanting with mandarin trees in both seasons.

\section{Land equivalent coefficient (LEC)}

Land equivalent coefficient (LEC) is a measure of interaction concerned with the strength of the relationship. Land equivalent coefficient (LEC) is used for a two- crop mixture the minimum expected productivity coefficient (PC) is 25 percent, that is, a yield advantage is obtained if LEC value was exceeded 0.25 . LEC values were greater than 0.25 in all the studied treatments (Table 8). LEC ranged from 0.34 by growing two soybean plants distanced at 25 $\mathrm{cm}$ between hills with mango trees to 0.48 by growing two soybean plants distanced at $50 \mathrm{~cm}$ between hills with mandarin trees in the first season. Also, LEC ranged from 0.35 by growing soybean in narrow distribution with mango trees to 0.48 by growing soybean in wide distribution with mandarin trees in the second one. The advantage of the highest LEC by growing two soybean plants distanced at $50 \mathrm{~cm}$ between hills (two soybean rows per ridge) with mandarin trees could be due to competitive pressure for basic growth resources between the intercrops was lower than the others.

\begin{tabular}{|c|c|c|c|c|c|}
\hline Treatments & $\begin{array}{c}\text { Soybean plant } \\
\text { distribution }\end{array}$ & $\begin{array}{c}\text { RY of } \\
\text { orchards }\end{array}$ & $\begin{array}{c}\text { RY of } \\
\text { soybean }\end{array}$ & LER & LEC \\
\hline \multicolumn{2}{|c|}{ Season } & \multicolumn{4}{|c|}{2018 season } \\
\hline \multirow[t]{3}{*}{$\begin{array}{l}\text { Soybean + } \\
\text { Orange }\end{array}$} & $\begin{array}{c}\text { Narrow } \\
\text { distribution }\end{array}$ & 1.01 & 0.40 & 1.41 & 0.40 \\
\hline & $\begin{array}{c}\text { Wide } \\
\text { distribution }\end{array}$ & 1.11 & 0.42 & 1.53 & 0.46 \\
\hline & Mean & 1.06 & 0.41 & 1.47 & 0.43 \\
\hline \multirow[t]{3}{*}{$\begin{array}{l}\text { Soybean + } \\
\text { Mandarin }\end{array}$} & $\begin{array}{c}\text { Narrow } \\
\text { distribution }\end{array}$ & 1.00 & 0.41 & 1.41 & 0.41 \\
\hline & $\begin{array}{c}\text { Wide } \\
\text { distribution }\end{array}$ & 1.08 & 0.45 & 1.53 & 0.48 \\
\hline & Mean & 1.04 & 0.43 & 1.47 & 0.44 \\
\hline \multirow[t]{3}{*}{$\begin{array}{l}\text { Soybean + } \\
\text { Mango }\end{array}$} & $\begin{array}{c}\text { Narrow } \\
\text { distribution }\end{array}$ & 0.99 & 0.35 & 1.34 & 0.34 \\
\hline & $\begin{array}{c}\text { Wide } \\
\text { distribution }\end{array}$ & 1.01 & 0.36 & 1.37 & 0.36 \\
\hline & Mean & 1.00 & 0.35 & 1.35 & 0.35 \\
\hline \multicolumn{2}{|l|}{ Season } & \multicolumn{4}{|c|}{2019 season } \\
\hline \multirow[t]{3}{*}{$\begin{array}{l}\text { Soybean + } \\
\text { Orange }\end{array}$} & $\begin{array}{c}\text { Narrow } \\
\text { distribution }\end{array}$ & 1.02 & 0.40 & 1.42 & 0.40 \\
\hline & $\begin{array}{c}\text { Wide } \\
\text { distribution }\end{array}$ & 1.09 & 0.43 & 1.52 & 0.46 \\
\hline & Mean & 1.05 & 0.42 & 1.47 & 0.43 \\
\hline \multirow[t]{3}{*}{$\begin{array}{l}\text { Soybean + } \\
\text { Mandarin }\end{array}$} & $\begin{array}{c}\text { Narrow } \\
\text { distribution }\end{array}$ & 0.99 & 0.42 & 1.41 & 0.41 \\
\hline & $\begin{array}{c}\text { Wide } \\
\text { distribution }\end{array}$ & 1.06 & 0.46 & 1.52 & 0.48 \\
\hline & Mean & 1.03 & 0.44 & 1.46 & 0.44 \\
\hline \multirow[t]{3}{*}{$\begin{array}{l}\text { Soybean + } \\
\text { Mango }\end{array}$} & $\begin{array}{c}\text { Narrow } \\
\text { distribution }\end{array}$ & 0.99 & 0.36 & 1.35 & 0.35 \\
\hline & $\begin{array}{c}\text { Wide } \\
\text { distribution }\end{array}$ & 1.00 & 0.36 & 1.36 & 0.36 \\
\hline & Mean & 0.99 & 0.36 & 1.35 & 0.35 \\
\hline
\end{tabular}

Table 8: RY of intercrops, LER and LEC of interplanting soybean with orchard tree species under two soybean plant distributions in both seasons.

These results are in accordance with those obtained by Selim., et al. [28] who revealed that there was an advantage of interplanting soybean variety Giza 22 with mandarin trees reflected on the highest LEC compared with the other treatments. 


\section{Economic return}

Total return

The economic return of interplanting soybean with orchard tree species under two soybean plant distributions is shown in table 9. Total return ranged from 1426.3 USD/ha by growing soybean in narrow distribution with orange trees to 9826.5 USD/ha by growing soybean in wide distribution with mango trees in the first season. Also, total return ranged from 1553.0 USD/ha by growing two soybean plants distanced at $25 \mathrm{~cm}$ between hills with orange trees to $10121.0 \mathrm{USD} /$ ha by growing two soybean plants distanced at $50 \mathrm{~cm}$ between hills with mango trees in the second one. It seems that the high price of mango fruits played a major role in increasing the total return of soybean + mango system compared with the prices of citrus fruits, as the price of mango fruits doubled about four times the citrus fruits with regardless to soybean plant distribution. Meanwhile, wide soybean plant distribution played an important role in increasing the total return of interplanting soybean with citrus trees.

\begin{tabular}{|c|c|c|c|c|c|}
\hline $\begin{array}{l}\text { Treat- } \\
\text { ments }\end{array}$ & $\begin{array}{l}\text { Soybean } \\
\text { plant dis- } \\
\text { tribution }\end{array}$ & $\begin{array}{c}\text { Income of } \\
\text { orchards } \\
\text { (USD/ha) }\end{array}$ & $\begin{array}{c}\text { Income of } \\
\text { soybean } \\
\text { (USD/ha) }\end{array}$ & $\begin{array}{c}\text { Total } \\
\text { return } \\
\text { (USD/ha) }\end{array}$ & MAI \\
\hline \multicolumn{2}{|c|}{ Season } & \multicolumn{4}{|c|}{2018 season } \\
\hline \multirow[t]{3}{*}{$\begin{array}{l}\text { Soybean } \\
+ \text { Orange }\end{array}$} & $\begin{array}{c}\text { Narrow } \\
\text { distribution }\end{array}$ & 845.8 & 580.5 & 1426.3 & 414.7 \\
\hline & $\begin{array}{c}\text { Wide } \\
\text { distribution }\end{array}$ & 932.4 & 616.5 & 1548.9 & 536.5 \\
\hline & Mean & 889.1 & 598.5 & 1487.6 & 475.6 \\
\hline \multirow{3}{*}{$\begin{array}{l}\text { Soybean } \\
+ \text { Manda- } \\
\quad \text { rin }\end{array}$} & $\begin{array}{c}\text { Narrow } \\
\text { distribution }\end{array}$ & 2444.2 & 594.0 & 3038.2 & 883.4 \\
\hline & $\begin{array}{l}\text { Wide } \\
\text { distribu- } \\
\text { tion }\end{array}$ & 2627.3 & 648.0 & 3275.3 & 1134.6 \\
\hline & Mean & 2535.7 & 621.0 & 3156.7 & 1009.0 \\
\hline \multirow[t]{3}{*}{$\begin{array}{l}\text { Soybean } \\
+ \text { Mango }\end{array}$} & $\begin{array}{c}\text { Narrow } \\
\text { distribution }\end{array}$ & 9220.0 & 513.0 & 9733.0 & 2469.5 \\
\hline & $\begin{array}{c}\text { Wide } \\
\text { distribution }\end{array}$ & 9300.0 & 526.5 & 9826.5 & 2653.8 \\
\hline & Mean & 9260.0 & 519.7 & 9779.7 & 2561.7 \\
\hline \multicolumn{2}{|c|}{ Season } & \multicolumn{4}{|c|}{2019 season } \\
\hline \multirow[t]{3}{*}{$\begin{array}{l}\text { Soybean } \\
+ \text { Orange }\end{array}$} & $\begin{array}{c}\text { Narrow dis- } \\
\text { tribution }\end{array}$ & 959.0 & 594.0 & 1553.0 & 459.3 \\
\hline & $\begin{array}{c}\text { Wide distri- } \\
\text { bution }\end{array}$ & 1022.3 & 679.5 & 1701.8 & 582.1 \\
\hline & Mean & 990.6 & 636.7 & 1627.4 & 520.7 \\
\hline
\end{tabular}

\begin{tabular}{|c|c|c|c|c|c|}
\hline $\begin{array}{c}\text { Soybean } \\
\text { + Manda- } \\
\text { rin }\end{array}$ & $\begin{array}{c}\text { Narrow dis- } \\
\text { tribution }\end{array}$ & 2537.4 & 612.0 & 3149.4 & 915.8 \\
\cline { 2 - 6 } & $\begin{array}{c}\text { Wide distri- } \\
\text { bution }\end{array}$ & 2697.3 & 693.0 & 3390.3 & 1159.8 \\
\cline { 2 - 6 } & Mean & 2617.3 & 652.5 & 3269.8 & 1037.8 \\
\hline $\begin{array}{c}\text { Soybean } \\
\text { + Mango }\end{array}$ & $\begin{array}{c}\text { Narrow dis- } \\
\text { tribution }\end{array}$ & 9570.0 & 526.5 & 10096.5 & 2617.6 \\
\cline { 2 - 6 } & $\begin{array}{c}\text { Wide distri- } \\
\text { bution }\end{array}$ & 9590.0 & 531.0 & 10121.0 & 2679.0 \\
\cline { 2 - 7 } & Mean & 9580.0 & 528.7 & 10108.7 & 2648.3 \\
\hline
\end{tabular}

Table 9: Financial return of interplanting soybean with orchard tree species under two soybean plant distributions in both seasons.

These results show that growing one soybean row per ridge in the soybean + mango system is more profitable for Egyptian farmers followed by growing two soybean rows per ridge with mandarin trees. These results are in agreement with Lachungpa [25] who revealed that interplanting some crops with mandarins provided farmers with increased food security and opportunities for cash flow.

Monetary advantage index (MAI)

The economic performance of the interplanting was evaluated to determine if soybean and orchards combined yields are high enough for the farmers to adopt this system. MAI ranged from 414.7 by growing two soybean plants distanced at $25 \mathrm{~cm}$ between hills with orange trees to 2653.8 by two soybean plants distanced at $50 \mathrm{~cm}$ between hills with mango trees in the first season. Also, MAI ranged from 459.3 by growing soybean in narrow distribution with orange trees to 2679.0 by growing soybean in wide distribution with mango trees in the second one. Differences between the highest and the lowest values were 2239.1 in the first season and 2219.7 in the second one. Growing soybean with mango trees resulted in high MAI followed by growing two soybean plants distanced at $50 \mathrm{~cm}$ between hills (two soybean rows per ridge) with mandarin trees. In this concern, Selim., et al. [28] indicated that growing soybean varieties Giza 22 and Giza 111 with mandarin trees was mainly influenced by the complementary effects between the both species which resulted in high MAI.

\section{Conclusion}

It can be concluded that sandy soils require a proper system to offer optimum productivity of interplanting soybean with orchard tree species. Although growing two soybean plants distanced at 50 
cm between hills with citrus trees recorded high productivity of both crops and land usage, growing two soybean plants distanced at $25 \mathrm{~cm}$ between hills in the soybean + mango system is more profitable under sandy soil conditions.

\section{Conflict of Interest}

No declare for financial interest or any conflict of interest exists.

\section{Bibliography}

1. Nakasone HY and Paull RE. "Tropical Fruits". CAB International, Wallingford, England (1998): 445.

2. Dugo G and Di-Giacomo A. "Citrus: the genus Citrus, medicinal and aromatic plants-industrial profiles". Taylor and Francis Group, London (2002).

3. Salem SE and Sheta I. "Citriculture and Genetic Resources in Egypt: State of the Art”. In: Proc. the Mediterranean Research Network on Certification of Citrus (MNCC): 1998-2001, D’Onghia, A.M., K. Djelouah and C.N. Roistacher (Eds.). Bari: CIHEAM (2002): 27-29.

4. FAO. "Citrus Fruit Fresh and Processed". Annual Statistics. Rome, FAO (2005).

5. CLAM (Comité de Liaison de l'Agrumiculture Méditerranéenne). "Les exportations d'agrumes du basin Méditerranéen". Statistiques evaluations repartitions situation, 2006-2007 (2007): 121.

6. Ahmed HF. "Phytohormones content and random amplified polymorphic DNA (RAPD) marker assessment of some Egyptian citrus cultivars". African Journal of Biotechnology 11 (2012): 15755-15762.

7. FAO. "Investing in agriculture for a better future". Annual Statistics. Rome, FAO (2012).

8. Abou-Zeed Eman AA., et al. "Effect of yeast and different phosphorus fertilizer sources on growth and fruiting of Balady mandarin trees". Assiut Journal of Agricultural Sciences 45.3 (2014): 49-64.

9. Abobatta W. "Improving Navel orange (Citrus sinensis L) productivity in Delta Region, Egypt". Advances in Agriculture and Environmental Science 2.1 (2018a): 8-10.
10. Abobatta W. "Challenges for citrus production in Egypt". Acta Scientific Agriculture 2.8 (2018b): 40-41.

11. Ploetz RC., et al. "Compendium of tropical fruit diseases". APS Press, St Paul, Minnesota, USA, (1994): 88.

12. Mukherjee SK. "Introduction: Botany and Importance". In: The Mango: Botany, Production and Uses. 1st edition (R. E. Litz Ed.), CAB International, Wallingford, UK (1997): 19.

13. Riad M. "Mango production in Egypt". Acta Horticulture (ISHS), (1997): 4552-4556.

14. Tharanathan RN., et al. "Mango (Mangifera indica L.), The King of Fruits": an overview". Food Review International 22 (2006): 95-123.

15. UNCTAD. "Mango: An INFOCOMM Commodity Profile; UNCTAD Trust Fund on Market Information on Agricultural Commodities". United Nations Conf. on Trade and Development (UNCTAD), United Nations: New York, NY, USA; Geneva, Switzerland (2016): 21.

16. Wutscher HK. "Soil pH and extractable elements under blight affected and healthy citrus trees on six Florida soils". Journal of the American Society for Horticultural Science 114 (1989): 611-614.

17. Derr JF. "Biological assessment of herbicides use in apple production II. Estimated impacts following loss of specific herbicides". Horticulture Technology 11.1 (2001): 20-25.

18. Stino RG., et al. "Productivity and fruit quality of three mango cultivars in relation to foliar sprays of calcium, zinc, boron or potassium". Journal of Horticultural Science and Ornamental Plants 3.2 (2011): 91-98.

19. Shaaban SHA., et al. "Nutritional status of soil and plant and nutrient discrimination factor of some irrigated olive orchards at the North West of Egypt". African Journal of Agricultural Research 11.34 (2016): 3232-3239.

20. McCauley A., et al. "Nutrient Management Module No. 8: Soil pH and Organic Matter". MSU Extension (2017).

21. Wolff MW., et al. "Tillage of a cover crop lowers net GWP and sequesters soil carbon in a California vineyard". Soil Tillage Research 175 (2018): 244-254. 
22. Yost JL and Hartemink AE. "Chapter four-Soil organic carbon in sandy soils: A review". Advances in Agronomy 158 (2019): 217-310.

23. Bulletin of Statistical Cost Production and Net Return. "Summer and Nili Field Crops and Vegetables and Fruit". Agriculture Statistics and Economic Sector, Ministry of Egyptian Agriculture and Land Reclamation, Part (2), Egypt, (2019).

24. Gliessman SR. "Multiple Cropping Systems: A Basis for Developing an Alternative Agriculture". Environmental Studies, University of California (1979).

25. Lachungpa K. "Intercropping of Agri/Horti Crops with Special Reference to Mandarin (Citrus reticulata Blanco) in Sikkim, India". ${ }^{\text {th }}$ International Crop Science Congress, Brisbane (2004).

26. Agreda FM., et al. "Effects of legumes intercropped in mango orchards in the Soconusco, Chiapas, Mexico". Tropentag 2006, University of Bonn, Conf. Int. Agric. Res. for Development (2006).

27. Mulinge JM., et al. "Effects of legume cover crops on orange (Citrus sinensis) fruit weight and brix". International Journal of Plant and Soil Science 21.4 (2018): 1-9.

28. Selim MAF., et al. "Interplanting some soybean cultivars with mandarin in sandy soil". Agricultural Sciences 11 (2020): 88110.

29. Mohta NK and De R. "Intercropping maize and sorghum with soybeans". Journal Agricultural Sciences Cambridge, 95 (1980): 117-122.

30. Addo-Quaye AA., et al. "Growth analysis of component crop in maize - soybean crops in maize - soybean intercropping system as affected by time of planting and spatial arrangement". ARPN Journal of Agricultural and Biological Science 6.6 (2011): 34-44.

31. Gadallah R and Selim T. "Distributions of soybean and corn plants in intercropping and solid patterns". Soybean Research 14.2 (2016): 1-18.

32. Chapman HD and Pratt PE. "Methods of Analysis for Soil, Plant and Water". Division Agric. Sci., California Univ., U.S.A (1961).
33. Gaur AC., et al. "A study of decomposition of organic matter in an alluvial soil. $\mathrm{CO}_{2}$ evolution microbiological and chemical transformation". Plant and Soil 34 (1971): 17-28.

34. Mead R and Willey RW. "The concept of a "land equivalent ratio" and advantages in yields from intercropping". Experimental Agriculture 16 (1980): 217-228.

35. Adetiloye PO., et al. "A land equivalent coefficient concept for the evaluation of competitive and productive interactions on simple complex mixtures". Ecological Modelling 19 (1983): 27 39.

36. Willey RW. "Intercropping its importance and research needs. Part I: Competition and yield advantages". Field Crops Abstract 32 (1979): 1-10.

37. Freed R.D. "MSTATC Microcomputer Statistical Program". Michigan State Univ. East Lansing, Michigan, USA (1991).

38. Gomez KA and Gomez AA. "Statistical Procedures for Agricultural Research". 2nd Edition, John Willey and Sons, Toronto, ON, Canada (1984).

39. Kolář L., et al. "Relationship between soil organic matter lability and liming requirement in acid sandy-loam cambisols". Plant Soil Environment 53.1 (2007): 24-32.

40. Seied NE., et al. "Effect of chemical fertilizers and bio-fertilizers application on some morpho- physiological characteristics of forage sorghum". International Journal of Agronomy and Plant Production 4.2 (2013): 223-231.

41. Doran JW and Zeiss MR. "Soil health and sustainability: managing the biotic component of soil quality". Agriculture, Ecosystems and Environment. Applied Soil Ecology 15 (2000): 3-11.

42. Feng L., et al. "The influence of light intensity and leaf movement on photosynthesis characteristics and carbon balance of soybean". Frontiers in Plant Science 9 (2019): 1952.

43. Jose S., et al. "Tree-crop interactions: Lessons from temperate alley-cropping systems". In: Batish, D.R., Kohli, R.K., Jose, S., Singh, H.P. (eds), Ecological basis of agroforestry. CRC Press, NW, USA, (2007): 15-36. 
44. Idso SB and Kimball BA. "Effects of long-term atmospheric $\mathrm{CO} 2$ enrichment on the growth and fruit production of sour orange trees". Global Climate Change 3 (1997): 89-96.

45. Dawah HA., et al. "The first occurrence of Coptops aedificator (Fabricius) (Coleoptera: Cerambycidae) a pest of cultivated mango in South-Western Saudi Arabia". Jazan University 2 (2013): 1-9.

46. Blair MW., et al. "Role of Legumes for and as Horticultural Crops in Sustainable Agriculture”. Chapter 9 In: Organic farming for sustainable agriculture, Springer International Publishing Switzerland (2016): 1-27.

47. Bhat R., et al. "Effect of intercrops on apple production cv. red delicious". International Journal of Current Microbiology and Applied Sciences 7.6 (2018): 1543-1550.

48. Chang JH. "Radiation balance. Climatic and Agriculture". An ecological survey, Aldine Publishing Company, Chicago, Illinois, USA, (1974): 4-22.

49. Odeleye., et al. "The Effect of light intensity on the growth, development and yield of soybean in Southwest Nigeria". African Crop Science Journal 9 (2001): 577-590.

50. Cox WJ and Cherney JH. "Growth and yield responses of soybean to row spacing and seeding rates". Agronomy Journal 103 (2011): 123-128.

51. Akond M., et al. "Effect to two row spaces on several agronomic traits in soybean [Glycine max (L.) Merr.]". Atlas Journal of Plant Biology 1 (2013): 18-23.

52. Avilan RL., et al. "Root system distribution in sweet orange (Citrus sinensis) and grapefruit (Citrus paradisi) on sour orange (Citrus aurantium) in calcareous soils of the Lake Valencia basin". Horticulture Abstracts 57.9 (1987): 771.

53. Kolář L., et al. "The demand of calcareous substances considering labile organic substances in soil, $\mathrm{CO}_{2}$ production and buffering system of soil and soil water". Proc. $11^{\text {th }}$ Int. Conf. Reasonable use of fertilizers, Czech University of Agriculture in Prague (2005): 79-86.

54. Vandermeer J. "The Ecology of Intercropping”. Cambridge University Press, New York (1989).

\section{Assets from publication with us}

- Prompt Acknowledgement after receiving the article

- Thorough Double blinded peer review

- Rapid Publication

- Issue of Publication Certificate

- High visibility of your Published work

Website: www.actascientific.com/

Submit Article: www.actascientific.com/submission.php Email us: editor@actascientific.com

Contact us: +919182824667 